\title{
Settler Witnessing at the Truth and Reconciliation Commission of Canada
}

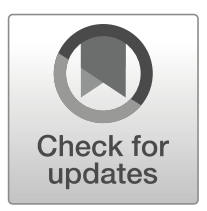

\author{
Rosemary Nagy ${ }^{1}$
}

Published online: 5 June 2020

(C) Springer Nature B.V. 2020

\begin{abstract}
This article offers an account of settler witnessing of residential school survivor testimony that avoids the politics of recognition and the pitfalls of colonial empathy. It knits together the concepts of bearing witness, Indigenous storytelling, and affective reckoning. Following the work of Kelly Oliver, it argues that witnessing involves a reaching beyond ourselves and responsiveness to the agency and self-determination of the other. Given the cultural genocide of residential schools, responsiveness to the other require openness to and nurturing of Indigenous ways of knowing and being. In order to illustrate the complexities and challenges of settler witnessing, the author reflects on her experiences in attending six of the TRC's national events and, in particular, what she has learned from Frederick "Fredda" Paul, Passamaquoddy Elder, healer, storyteller, and residential school survivor. The article analyzes (1) aesthetics and emotions in the staging of TRC events and (2) making meaning over time and the temporality of transitional justice.
\end{abstract}

Keywords Truth and Reconciliation Commission ofCanada - Bearing witness - Indigenous storytelling · Testimony · Affective reckoning · Settler colonialism · Transitional justice · Temporality

\section{Introduction}

From 2010 to 2015, the Truth and Reconciliation Commission (TRC) of Canada bore witness to and collected testimony from over 6750 survivors of Indian residential schools (TRC 2015c, p. 1). It hosted 7 national truth and reconciliation events and 17 community or regional hearings where survivors and their families shared their truths in public or through private statements. There were significant media coverage

Rosemary Nagy

rnagy@ nipissingu.ca

1 Department of Gender Equality and Social Justice, Nipissing University, 100 College Drive, Box 5002, North Bay, ON P1B 8L7, Canada 
and livestreaming of events, and there is now a large video archive hosted online by the National Centre for Truth and Reconciliation. Drawing on survivor testimony, historical research, and analysis of the intergenerational legacies of residential schools, the TRC determined that the residential school system was "cultural genocide."

Despite the abundance of testimonials, studies, and information, many settler Canadians continue to downplay the nature and extent of the harms of residential schools and deny subsequent obligations to redress historic and ongoing colonialism as the prerequisite for reconciliation (Jung 2018). While there are many reasons for settler denial, philosopher Anna Cook argues that we need to "complicate the assumption that non-Native Canadians simply need to hear testimonies of residential school survivors in order to challenge their historical amnesia" (Cook 2017, p. 80). As public memory scholar Roger Simon puts it, "there is a difference between learning about and learning from" the residential schools' history (Simon 2013, p. 136).

This paper takes up the question of how settlers might learn from survivors' stories by developing an account of settler witnessing. I argue that to meaningfully bear witness in the context of Indigenous genocide, we must open our hearts and minds to Indigenous ways of knowing and being in the world. This is because the residential school system sought to destroy Indigenous culture, tradition, and knowledge as a means of "eliminating the Native," who stands as an obstacle to the settler's "insatiable" need for land (Wolfe 2006). Opening our hearts and minds to Indigenous ways of knowing and being serves to honor Indigenous resistance and resilience. Witnessing can also function as a form of settler accountability, but only when the process of witnessing leads to the disruption of colonial narratives, a reckoning of complicity, and decolonizing change.

The paper proceeds in the spirit of "Two-Eyed Seeing," which is Mi'kmaw Elder Albert Marshall's term for the weaving together of Indigenous and Western knowledges that draws on the strengths of each "for the benefit of all" (Bartlett et al. 2012, p. 335). Drawing on Western accounts of the ethics of witnessing and the work of philosopher Kelly Oliver (2001) in particular, I understand bearing witness to be an experience grounded in agency, sense of self, and responsiveness to the other. In the settler colonial context, responsiveness to the other means honoring "Aboriginal principles of witnessing," as per the TRC's mandate, as well as the broader relational ethics of Indigenous storytelling, which center on principles of respect, reciprocity, responsibility, and reverence (Archibald 2008). However, for settlers, this is no easy process because of our rootedness in colonialism. Thus, I turn to the idea of "affective learning" (Korteweg and Root 2016) to explain how settlers might process difficult emotions over time in order to act with justice and compassion.

In order to illustrate the contours of settler witnessing, I reflect upon my own experiences in attending six of the TRC's national events. ${ }^{1}$ In particular, I share what I have learned from Frederick "Fredda" Paul, Passamaquoddy Elder, storyteller and healer, whose residential school stories I first heard at the TRC's Atlantic event in October 2011. I contacted Fredda in 2016 because his stories had stayed with me since I first heard them, and I wanted his permission to write about why they were so compelling. Fredda and I subsequently developed a relationship, and he is the inspiration for this research. While Fredda's stories are not mine to share, our conversations,

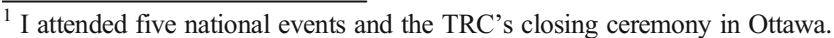


his teachings, and my bearing witness to his truths deeply inform this work. I also acknowledge the input and assistance of Leslie Wood, Fredda's friend who read his stories aloud at the TRC event and is now working with Fredda to turn his stories into a book. $^{2}$

Retrospective reflection and analysis of my continuing journey provides insight into white settler culture more broadly. The very experience of bearing witness is socially embedded; our perceptions of testimony are filtered through culture, politics, bias, stereotypes, etc. (Saeidi and Turcotte 2011). This self-reflective approach means that the paper is focused on the internal process of witnessing survivor testimony and the challenges of unsettling - what Paulette Regan describes as a loosening, perturbing, or agitating, in order to "risk interacting with Indigenous peoples differently... and a willingness to stay in the decolonizing struggle of our own discomfort" (Regan 2010, p. 13). Settler decolonization (of and by settlers) must continue beyond the life of the truth commission. My interest here is the ways in which survivor testimony might spark or strengthen settler reckoning and decolonizing change through the dismantling of colonial attitudes, beliefs, institutions, and structures. I view these as intermediary steps in the transformation of Indigenous-settler relationships that, ultimately, requires the return of Indigenous life and land.

The theory of settler witnessing is one that moves, in Oliver's (2001) words, "beyond recognition." The notion of recognition gained currency in the 1990s with identity politics that challenged difference-blind liberalism. On this account, the subaltern demand for the recognition of diversity and specificity (i.e., gender, race, sexual orientation, ability) responds to a "vital human need" (Taylor 1994, p. 26). The need for recognition is based on Hegelian understandings of self-consciousness as being inherently intersubjective. That is, one's sense of self is formed in dialogue, agreement, or struggle with others, and autonomy and authenticity are therefore grounded in mutual recognition. Hence, misrecognition is not simply a matter of lack of respect, but is experienced as a "grievous wound," including through the internalization of inferiority (ibid).

While this theory of misrecognition captures the psycho-affective workings of colonialism, it fails to account for the historical and material conditions that structure misrecognition, namely, territorial expansion and colonial-capitalist exploitation (Coulthard 2014; Fanon 1952). In particular, it fails to acknowledge that the conditions for mutual recognition simply do not exist given the power differentials of settler colonialism; rather, minority groups and Indigenous peoples experience recognition as conferral by the state (Coulthard 2014; Oliver 2015). Later in the essay, I explain how the politics of recognition - or what Dene scholar Glen Coulthard (2014) calls "colonial recognition"-inform settler visions of reconciliation that stop well short of dismantling colonial structures and returning Indigenous land. In contrast, because settler witnessing moves "beyond recognition," it opens a window for decolonizing change.

I further hold that settler witnessing needs to operate within "temporal pluralities" that affirm Indigenous sovereignty and futurity (Rifkin 2017). This sharply contrasts

\footnotetext{
${ }^{2}$ I hope readers will want to read Fredda's book when it comes out. For further information, please contact Leslie Wood at wildwoodleslie@hotmail.com. Fredda would like to thank all the people who have been involved in helping to write out his stories and develop his book. Fredda intends the stories in his book to be read out loud, in keeping with oral tradition and for better understanding.
} 
the linear temporality that pervades transitional justice. As Zinaida Miller writes, transitional justice exercises "temporal governance" in problematic, yet frequently unremarked ways. Temporal governance includes the predominant conceptualization of transitional justice as drawing a line between past and future, failing to attend to the gap between "institutional temporalities and lived time," and imposing colonial time (Miller forthcoming, p. 12). These forms of temporal governance are present in the Canadian context, such as with the state apology for residential schools, which calls for closing this "sad chapter in our history" and asks all Canadians to "move forward together in partnership." The apology ignores contemporaneous, ongoing colonialism and requests Indigenous peoples to progress through Eurocentric timelines of "moving forward" that exclude the return of land and other substantive measures.

In general, governance through settler colonial temporality casts Indigenous peoples as ahistorical and anachronistic. ${ }^{3}$ Notably, the underlying premise of residential schools was to modernize the primitive and civilize the savage. Nineteenth century management of the "Indian problem" intertwined the colonial desire for land and the need for territorial expansion with rationales about the childlike qualities of Indigenous peoples that necessitated Crown protection (fiduciary trust) of dispossessed lands (de Leeuw 2009). Residential schooling was a key component of this strategy: Indigenous children, as members of a childlike race, could only attain adulthood by meeting colonial standards of Whiteness, including the proper use of (private propertied) land through agricultural training (ibid). These modes of temporal management carry though today with the Crown's ongoing fiduciary role and the 1876 Indian Act, which still governs almost every aspect of Indigenous life. ${ }^{4}$ Furthermore, the dichotomization of tradition and modernity in the settler colonial imagination creates "a fantasized construction of Indian realness cast as immanently tied to a bygone era" (Rifkin 2017, p. 7). Yet, Indigenous peoples must also repeatedly demonstrate that they are just as modern as settlers (ibid.).

Arguably, settler temporality forms part of the background that influences how settlers receive and filter survivor testimony. Embracing survivor testimony through the frame of Indigenous storytelling thus requires temporal reorientation on the part of settler witnesses, an acknowledgement that Indigenous peoples and cultures are "livingin-time," as Mark Rifkin (2017) puts it. Rather than assimilating Indigeneity into colonial temporality, settler witnessing attends to "peoples' own frames of reference for their experiences of time... as a basis for understanding the materiality of their ways of being and becoming" (Rifkin 2017, p. 31). Rifkin calls this "temporal sovereignty."

In the remainder of the paper, I first provide context on the politics of truth and reconciliation in Canada. Next, I develop the theory of settler witnessing, which denotes a specifically ethical process, as opposed to merely "watching," "learning

\footnotetext{
${ }^{3}$ Consider John Borrows' (2017) observation that in contrast to the "living tree" doctrine that applies to the rest of Canada, the Supreme Court of Canada has ruled that Indigenous peoples must demonstrate that protected practices, customs, and tradition were "integral to a distinctive culture" prior to European contact (van der Peet 1996). Thus, the Constitution is interpreted as only protecting traditional land uses - hunting, fishing, trapping - and not, for example, the establishment of gambling activities on reserve land. (The living tree doctrine holds that the Constitution must be read in a broad and progressive manner that keeps up with the times.)

${ }^{4}$ The legal and sociopolitical evolution of the Indian Act and fiduciary trust, including reasons Indigenous peoples may have for not dismantling them, are beyond my scope. My point here is simply that the paternalistic role of the state remains in place.
} 
about," or, worse, "consuming" trauma narratives. I then turn to the experience of witnessing at the TRC. My analysis of the TRC is confined to two main aspects as relates to the spaces it created for truth-telling and bearing witness: (1) aesthetics and emotions in the staging of TRC events and (2) making meaning over time and the temporality of transitional justice. This latter aspect analyzes in particular how time has affected Fredda's story and my perceptions of it.

Throughout, I use the terms "public narration," "testimony," "truth-sharing," and "storytelling" all somewhat interchangeably; the use of "story" is not meant to diminish or demean survivors' testimony but to invoke the idea of Indigenous storytelling. Fredda and I have spoken at length about the paper, he has made specific changes to it, and, with his permission, I have added some of his comments or answers to questions that arose during our conversations. This aligns with Indigenous conversational methods where relationships evolve between "sharing story and listening," and where the research has a decolonizing purpose and is collaborative, informal, flexible, and reflexive (Kovach 2010).

\section{The Politics of Truth and Reconciliation in Canada}

The residential school system operated from the 1880s until 1996 and affected over 150,000 First Nations, Inuit and Métis children, and their families. The residential school system was funded by the Federal government and operated by the Roman Catholic, Anglican, United, Methodist, and Presbyterian churches in Canada. The explicit purpose of residential schools was to "kill the Indian in the child" by disrupting the transmission of Indigenous language, culture, and identity from one generation to the next. Children as young as 4 years old were removed, often forcibly, from their families and communities in order to be assimilated into settler society that was in reality unwilling to accept them. Alongside the everyday suffering of loneliness, hunger, illness, racism, and neglect, there was rampant and systemic sexual, physical, and psychological abuse.

Starting in the late 1980s, survivors of residential schools fought for justice in the courts for over twenty grueling years. Throughout the litigation stage, the state and churches repeatedly and consistently sought to isolate "individual" acts of abuse from the broader colonial project. When the courts certified a large class action suit invoking "loss of culture" as a tort, the government and churches finally chose to settle out of court. This decision was significantly due to looming liabilities rather than a desire to see justice done (Nagy 2014; Thielen-Wilson 2014). The subsequent 2007 Indian Residential Schools Settlement Agreement provides $\$ 2.1$ billion for compensation, commemoration, and the Truth and Reconciliation Commission. The Common Experience Payment is in explicit recognition of loss of family, community, and culture while the Independent Assessment Process is for specific acts of physical, sexual, and psychological abuse. The TRC, in turn, was mandated to promote public awareness and education and to "guide and inspire a process of truth and healing, leading toward reconciliation within Aboriginal families and between Aboriginal peoples and non-Aboriginal communities, churches, governments, and Canadians generally" (TRC 2015b, p. 23). 
Canada's TRC is unique compared with other truth commissions in the world. There is no post-conflict and no regime change, and Indigenous peoples comprise only $6.2 \%$ of the Canadian population (Statistics Canada 2017). Nonetheless, the TRC might be considered a mechanism of transitional justice insofar as it seeks to move Canada from less just to more just relations (Balint et al. 2014). Indeed, the TRC defined reconciliation as "an ongoing process of establishing and maintaining respectful relationships" (TRC 2015b, p. 23). The Commissioners frequently noted that the truth commission belonged to residential school survivors because it was "their settlement." The mandate established a Survivor Committee for consultation, participation, and engagement in the TRC process. The TRC had no power to name names or issue subpoenas, and thus did not seek individual accountability. This part of the mandate also prevented the TRC from making a finding of outright genocide; its use of "cultural genocide" worked around the culpability limitation. According to Commissioner Marie Wilson, "cultural genocide" was a way of honoring the trust that survivors put into the truth commission - and many survivors clearly voiced their experiences as genocidewithout breaking the rules of the mandate (MacDonald 2019, p. 126). ${ }^{5}$ In short, the TRC was designed to be and operated as a victim-centered truth commission with heavy emphasis on survivors' experiential knowledges and the "bottom-up" production of counter-narratives to the Canadian myth of benign colonialism (James 2012).

There are, of course, multiple risks with a victim-centered approach, as has been noted in various transitional justice contexts. For instance, critics of the South African TRC argued that the foregrounding of victims' stories of trauma served to isolate specific violations from the overarching crime of apartheid, thereby releasing the beneficiaries of apartheid from taking responsibility (Mamdani 1996). The therapeutic ethos sidesteps deep structural inequalities, while also risking the pathologization of victims and a flattening of diversity (Moon 2009). Furthermore, a victim-centered approach may prioritize particular kinds of testimony and silence others, notably gender-based and sexual violence (Kent 2014; Porter 2016; Ross 2010). There is also the "impossibility of bearing witness" to one's own trauma because felt pain exceeds the bounds of language and comprehension (Henry 2010; Scarry 1985). This compounds the pathologization of victims and potentially subjects their testimony to accusations of noncredibility.

Even when witnesses respond with empathy, rather than pathologization, it may be a "passive empathy" that fails to produce action toward social justice or critical selfreflection about complicity (Boler 1997, p. 259). Rather, all that may occur is feeling good about "feeling bad" (Ahmed 2005). This allows the witness to confirm to herself, and perhaps to others, that she is a good person. Alternatively, empathy might provoke a misguided desire to "help" the seemingly dysfunctional other, rather than challenging one's own group as the source of the problem. In the settler colonial context, this amounts to searching for new ways to fix the "Indian problem" (Regan 2010, p. 11). Athabaskan scholar Dian Million argues that settler governmentalities then position healing from trauma as a prerequisite for Indigenous self-determination: "The space of

\footnotetext{
${ }_{5}^{5}$ The plural interpretations of genocide are beyond my scope. In this essay, I tend to use the TRC's terminology, but here acknowledge that colonial genocide extends beyond cultural destruction to include the forcible transfer of children (Genocide Convention), ontological destruction (Woolford 2009), genderbased sexual violence (NIMMIWG 2019), and land and environment, as per Indigenous cosmologies (see MacDonald, 2019).
} 
our medicalized diagnosis as victims of trauma is not a site wherein self-determination is practiced or defined" (Million 2013, p. 150).

The rise of trauma discourse within transitional justice also contributes to temporal governance by isolating specific acts of abuse from structural and colonial violence (Miller forthcoming). In the residential school context, talk of intergenerational trauma and historical trauma is omnipresent, including within Indigenous communities. However, whereas Indigenous healing frameworks insist on the need for structural change, Western psycho-medical models tend to focus on individualized therapy (Episkenew 2009; Green 2012; Kirmayer et al. 2014). Furthermore, testimony relating to childhood experiences may have the effect of freezing survivors in time, as perennially helpless children, and this may reinforce the infantilization of Indigenous peoples as unfit for self-determination (Schaffer and Smith 2004). As noted in the introduction, state narratives of "closing this sad chapter" and "moving forward" invokes settler temporalities, thereby denying the temporal sovereignty of Indigenous peoples. Moreover, halfway through the operation of the TRC, then Prime Minister Stephen Harper boldly declared that Canada had "no history of colonialism."

Harper's attempt at historical erasure speaks to the broader sociopolitical environment in which the TRC operated. It is important to note that prior to the start of the TRC, only one in two Canadians were aware of the existence of Indian residential schools. This number rose to $66 \%$ by the conclusion of the TRC's work (Environics Institute for Survey Research 2016, p. 29). Hence, a significant number of Canadians have now learned about residential schools. This is a considerable achievement given the low baseline. But the question remains, what have settler Canadians learned from the residential schools history? A 2016 survey shows that $42 \%$ felt that "Canada's residential schools policy was not an intentional effort to destroy Aboriginal culture and connection to land," while $11 \%$ had no opinion (ibid., 31). In other words, they did not accept the TRC's finding of cultural genocide. Perhaps most telling, settler Canadians overwhelmingly believed that better relations with Indigenous peoples start with "learning about the historical abuses and discrimination that Aboriginal peoples have faced in Canada" (ibid., 6; emphasis mine). These survey results align with findings that media coverage during the TRC produced "overwhelmingly quietistic [superficial] rather than substantive" understandings of reconciliation that emphasized "comity and fence-mending" rather than decolonizing change (James 2017, p. 365; Nagy and Gillespie 2015).

In many regards, there are grounds to confirm Coulthard's (2014) assertion that the politics of reconciliation and the politics of recognition are very close (see also Cook 2018). As noted in the introduction, because recognition is ultimately conferred or granted by the state, it is unable "to significantly modify, let alone transcend, the depth of power at play in colonial relationships" (Coulthard 2014, p. 31). A prime example is the 1995 Supreme Court decision on constitutional protections for Aboriginal rights. This decision states that Indigenous peoples must demonstrate that protected practices, customs, and tradition were "integral to a distinctive culture" prior to European contact. ${ }^{6}$ It further makes clear that the pre-existence of Indigenous societies "is acknowledged and reconciled with the sovereignty of the Crown" (Van der Peet 1996, art. 31) and not, as Michael Asch (2014) notes, the other way around. Van der

\footnotetext{
${ }^{6}$ See footnote 3 above with regard to temporal governance.
} 
Peet sets the framework for subsequent "Crown-centric" (Imai 2017) jurisprudence, including the ability of the Crown to determine what constitutes justifiable infringement of Aboriginal rights - a list that comprises "virtually any economic exploitive venture" (Coulthard 2014, p. 41). ${ }^{7}$ This is not mutual recognition. This is assimilative reconciliation.

Post-TRC, the government has launched an agenda for reconciliation with a "Recognition and Implementation of Indigenous Rights Framework" (Canada 2018a) and a set of 10 principles aimed at "transformative change" for a renewed relationship (Canada 2018b). The degree to which this agenda will destabilize the constitutional framework explained above remains tenuous at best. ${ }^{8}$ The "Principles" document retains the language of van der Peet, and Canada problematically insists that constitutional law provides a "full box of [Aboriginal] rights" (Canada 2018b, p. 3). Although the promised implementation of UNDRIP could significantly correct the existing imbalance of power, the government indicates that Canadian constitutional law will remain supreme (King and Pasternak 2018; Nichols 2018; Patzer 2019). This seriously undermines the TRC's instruction to implement UNDRIP as a "framework for reconciliation." King and Pasternak, in their analysis of the "Rights Framework," conclude that while there are some "welcome changes" and "reconciliatory" proposals, "there is also a clear attempt to maintain a modified version of the status quo" (King and Pasternak 2018, p. 5). Among other things, they point to the policy's neglect of land restitution and treaty obligations, and a vision of self-determination that is confined to reserve land and exercised through Indian Act governance structures (Band Councils) rather than self-determination across traditional lands through traditional governance structures. $^{9}$

The TRC's 2015 final report articulated a highly substantive vision of reconciliation, with 94 Calls to Action in the areas of justice, treaty rights, education, child welfare, health, MMIWG2S, and language and culture. The government has thus far completed eight fairly easy recommendations in areas of funding for arts, sports, and language rights, and it established a National Inquiry on MMIWG2S. Understandably, some recommendations will take longer to implement, and there are a significant number of projects proposed or underway (CBC News 2020). Nonetheless, progress with regard to structural racism has been "minimal and cosmetic" at best (Jewell and Mosby 2019). In particular, the government has failed to acknowledge genocide officially, continues to fight against a Human Rights Tribunal decision regarding discrimination in First Nations child welfare, has not as yet substantially responded to report of the National Inquiry on MMIWG2S (and its finding of genocide), and is mired in multiple controversies over resource extraction projects on Indigenous land (MacDonald 2019; McIvor 2020).

\footnotetext{
${ }^{7}$ Delgamuukw v. British Columbia [1997] 1 SCR 1010.

${ }^{8}$ The agenda was shelved until the Fall 2019 election, which resulted in a minority government, and then COVID shortly followed.

${ }^{9}$ This became a national issue in winter 2020 when Wet'suwet'en hereditary chiefs protested the installation of a pipeline on traditional lands, although most of the affected Band Councils had approved the pipeline. Allied protestors (both Indigenous and non-Indigenous) set up road and railway blockades across the country, slowing the economy. One protest slogan was "\#ReconciliationIsDead." The blockades came down in February 2020 and at time of writing (May 2020), the issue is still being resolved (and this has been slowed by COVID).
} 
In summary, at work here is state willingness to recognize what Sheryl Lightfoot (2016) calls the "soft" rights to Indigenous culture, but not the "hard" rights (land, resources) to Indigenous self-determination. This observation aligns with the general criticism that the politics of cultural recognition distracts from socioeconomic redistribution (Fraser 2000). To be clear, I am not denying the importance of rights to culture, particularly in the context of cultural genocide. The problem, however, is that cultural recognition is occurring within the parameters of settler colonialism. That is, there is a general failure to acknowledge that there are structural and political implicationsindeed obligations - that come with recognizing Indigenous rights to culture. Specifically, I am referring to Indigenous temporality and land/nonhuman relationality that are part and parcel of Indigenous knowledges and holistic worldviews. In other words, culture extends to the "hard" rights.

Cook (2018) contends that the TRC was "immersed" within, "framed by," and "embraced" the politics of recognition and was therefore incapable of addressing settler ignorance or transforming relationships. She argues that the TRC embraced the politics of recognition through its assumption that "there must be recognition of the experiences of survivors of residential schools in order to have reconciliation" (Cook 2018, p. 10). Indeed, in its final report, the TRC writes that it placed the testimonies of survivors at the center of new pathways toward "truth, healing, justice," without which there can be "no genuine reconciliation" (TRC 2015a, pp. vol. 6, 7). Cook's main argument is that the TRC's focus on survivor testimony rendered it unable to challenge settler "common sense" knowledge that relegates sad stories about residential schools to the past. While I certainly agree that victim-centrism may lend itself colonial forms of recognition, I am less willing to blame the TRC or dismiss its work, as Cook sometimes implies we should do.

This is because there are also strengths to victim-centered truth commission, some of which directly counteract the risks. First, after decades of shame, silence, and state denial, the ability of survivors to speak their truths and be officially validated and acknowledged is crucial (James 2012). Some survivors spoke about their experiences for the very first time at the TRC. Sometimes they spoke directly to family and community members, apologizing to their children, and seeking to repair intimate relationships. In these acts, survivors "assert[ed] their own agency and empowerment over the process" (Angel 2012, p. 209). Second, the "transgressive potential" (James 2012) of survivor testimony was also evident in statements that directly challenged colonial narratives or government policy. Third, Cook should accord more weight to the Calls to Action. Fourth, as Cook herself argues, "Indigenous voices are necessary in order to expose these epistemic structures [of ignorance]" (2018, p. 21). What she misses, however, is that through the centrality of survivor testimony, the TRC contained within itself another mode of witnessing, one that goes beyond colonial recognition.

This understanding of witnessing, which I develop in the section below, nurtures agency, response-ability, and openness to the other. The TRC embedded these possibilities through the inclusion of Indigenous ceremony, oral history, and traditional knowledges into its process. The public testimonies of survivors, Elders, and others "constitute a new oral history record, one based on Indigenous legal traditions and the [Indigenous] practice of witnessing" (TRC 2015a, pp. vol. 6, 7) To be clear, in what follows, I am not arguing that the TRC perfectly or completely effected this mode of 
witnessing. However, I am developing an alternate account of how settlers might respond more robustly to survivor testimony within and outside the TRC structure. Survivor testimony is an important point of contact for settler Canadians precisely because of its emotional impact and concreteness - in comparison with more abstract issues like, say, sovereignty or legal pluralism. Survivors' stories provide a bridge or a window onto wider issues, and they invite, demand even, an ethical response to "both story and teller" (Schaffer and Smith 2004, p. 6). The massive online video archive of survivor testimony is a powerful resource, although as I discuss in the final section of the paper, we must be careful of how we use it. First, however, I theorize how ethical settler witnessing might occur.

\section{Bearing Witness, Indigenous Storytelling, and Affective Learning}

As a child living in Pleasant Point (Sipayik), Maine, Fredda Paul, along with his brother, was kidnapped by his father and taken to Shubenacadie Residential School in Nova Scotia. It took many years for his mother and grandmother to find him and bring him and his brother home. At the TRC in 2011, during almost thirty minutes of testimony, Fredda's friend, Leslie Wood, read aloud from the collection of stories that Fredda had narrated to her over the course of many early mornings and many years. Fredda himself spoke a little at the end. While Fredda experienced terrible abuse at Shubenacadie, his testimony was filled with stories of resistance and agency: a story about rescuing his younger friend from the clutches of an abusive priest; a story about taming the bull that he had been locked up with in the pen as punishment; and stories about stealing milk to feed the little ones in the dormitory and how the kids would find ways to make one another laugh because "Shubie" "was such a sad place."

Fredda's stories resonated with me, and I contemplated their meaning and impact for a long time. I showed the TRC's online video of his testimony to several classes because I thought it provided such a powerful teaching. When I reached out to Fredda and Leslie in 2016, I learned that he was working on a book, filled not only with stories specific to life at Shubenacadie but also stories about Passamaquoddy culture, teachings, and life at home, in particular the important role of his grandmother, who taught him the medicines to become a healer. Indigenous storytelling, writes Qwul'shi'yah'maht (Coast Salish), is "vital to the survival of Indigenous people" (2015, p. 178). In Indigenous cultures, storytelling provides a sense of identity and belonging. It "keeps the teaching and protocols of our Ancestors, culture and tradition alive," and it provides important counter-narratives to dominant colonial myths (Qwul'sih'yah'maht, 2015, p. 183) Indeed, Fredda's testimony at the TRC, as well the entirety of his storytelling, speaks to the "survivance" 10 of Indigenous culture and spirituality.

In the transitional justice context of genocide or mass atrocity, testimony conveys more than juridical or historical facts. Felman and Laub's (1992) seminal work on witnessing the testimony of Holocaust survivors explains testimony as a "mode of

\footnotetext{
${ }^{10}$ Anishinaabe writer and theorist Gerald Vizenor (2009), coins the term, "survivance" to capture the practices of survival, resistance, and endurance that "creat[e] a sense of native presence and actuality over absence, nihility [nothingness], and victimry." Survivance stories actively reject genocide, cultural domination, and images of passive and dysfunctional victims.
} 
access" to truth that is "beyond what is available as statement." To testify "is to give reality to one's own vulnerability" (29) and to the "very secret of survival and of resistance to extermination" (62). Laub identifies three levels of witnessing: first is "the level of being a witness to oneself within the experience" (75). The second level is the experience of being a witness to the testimony of others, and the third level "is the one in which the process of witnessing is itself being witnessed" (76). Witnessing is therefore necessarily dialogical and relational. Moreover, it is performative: in the process of bearing witness to another, what "ultimately" matters is "not simply the information, the establishment of acts, but the experience itself of living through testimony, of giving testimony" (85; italics original).

In other words, something unique emerges from within the multileveled structure of witnessing. Oliver, building on Felman and Laub's work, starts from the idea that trauma and oppression damage subjectivity. Subjectivity refers to one's sense of self and agency, and it is founded upon "the ability to respond to, and address, others" (Oliver 2001, p. 15). Address-ability and response-ability - in essence, witnessing - are embedded in subjectivity because we are fundamentally connected to other people and our environment (Oliver 2001, p. 15; Oliver 2015). While Oliver agrees with the supposition that we understand ourselves as agents through relations with others, she rejects the Hegelian notion that recognition occurs through struggle. She further argues that recognition is distributed along axes of power. Therefore, recognition is not mutual but experienced by marginalized groups as a conferral from the dominant group.

Oliver instead roots witnessing in the idea of subjectivity itself - that is, how we perceive ourselves and how we accordingly act in the world. In witnessing, we address and respond to one another as agential subjects. Witnessing conceived as response-ability and responsibility toward others necessarily entails an "open[ing] up rather than clos[ing] off of the possibility of response by others" (Oliver 2015, p. 15). I interpret the "possibility of response by others" to mean the nurturing of and respect for the self-determination and agency of the other. Oliver also calls for critical self-reflection, which is "a turn toward otherness," as we interrogate our roles in structures of domination and seek to transform our society (Oliver 2001, pp. 218-219). Oliver's theorization importantly moves us beyond that which can be recognized to "the process of witnessing itself" (2001, p.20). However, unlike Felman and Laub's model of witnessing, Oliver does not presuppose empathy or vicarious identification with the teller. Moreover, her emphasis on embodied and ecological relationality shares affinities with Indigenous worldviews (Oliver 2015). But, if we truly want to commit to Oliver's argument that witnessing requires an openness to the other, we must move beyond Western paradigms and shift the epistemological and ontological framework toward Indigenous storytelling and "Aboriginal principles of witnessing."

Stó:lō scholar Jo-ann Archibald explains that Indigenous "storywork" can vary from "the sacred to the historical, from cultural traditions to personal life experiences and testimonials" (2008, p. 83). Not all people who know stories and oral traditions will necessarily have the "gift" or the authority to become a storyteller (ibid., 69). Likewise, perhaps not all survivor testimony shared at the TRC might be considered storytelling; some of the testimony I saw was quite raw, unpolished, or difficult to follow. Yet, as Julia Emberley explains, there are clear affinities between testimony and Indigenous storytelling. 
Drawing on Felman and Laub's work, Emberley argues that testimony and Indigenous storytelling share "a genuine desire to reach out beyond the known" (Emberley 2014 , p. 54). Both have multiple layers of meaning, where we must pay attention to the metaphorical, not just the literal. Emberley describes this as a "process in which listening and learning are transformed into knowledge, but just what that knowledge is, is not always evident" (ibid., 55). Similarly, meaning-making within Indigenous storytelling practices unfolds over time and in different contexts. Emberley thus concludes, "the production of residential school testimony [through the TRC] is not entirely disconnected from the cultural production of Indigenous storytelling" (ibid., 56). Survivors' testimonial stories are steeped with multiple layers that "give meaning to the facts of [people's] lives" (Bidwell 2012). The stories sit with us, the listeners, as we unfold and make sense of these layers (Felman and Laub 1992, p. ch. 1; Qwul'sih'yah'maht, 2015).

The TRC mandate calls for the use of "Aboriginal principles of witnessing" at national and community events. The mandate does not explain what this means; the TRC posted its understanding in 2009. Noting the variance in witnessing among First Nations, Métis, and Inuit peoples, the TRC explains as follows:

Generally speaking, witnesses are called to be the keepers of history when an event of historic significance occurs. Partly because of the oral traditions of Aboriginal peoples, but also to recognize the importance of conducting business, building and maintaining relationships in person and face to face . . . witnesses are asked to store and care for the history they witness and most importantly, to share it with their own people when they return home (TRC 2015b, p. fn32).

There are commonalities across Indigenous ways of knowing and being that are embedded within holistic worldviews that emphasize connection, harmony, and balance (Castellano 2005). These interconnections are apparent in Susan Dion's (Potawatami/Lenape) observation that, "As a witness, I am called upon to listen and remember. As a witness, I have an obligation to listen and pass on that which I have heard, seen, and felt, not just as an individual but as an individual connected to others" (Dion 2009, pp. 18, emphasis added). Indigenous storytelling is a "social activity" that is part of the "equipment for living" (Cruikshank 1998, p. 41). The meaning of stories is not reified, but created through the "everyday situations in which they are told" (Cruikshank 1998, p. 2). Despite the loss of culture through colonial violence, Indigenous storytelling is reoriented and recreated as "part of a people's experiences of their own duration" (Rifkin, 2017, p. 26). Thus, indigenous storytelling can be an act of resistance and challenge, as well as a process of communication that creates connections between "past and future, between people and place" (Cruikshank 1998, p. 2).

Settler temporalities "conceptualize time as spatially laid out, mechanically segmented, and linear" (Cruikshank 1998, p. 155). This serves as the rationale for territorial expansion and the subjugation of those who do not fit the "story of... a chronogeopolitics of advancement" (Rifkin 2017, p. 53). In contrast, the temporalities invoked in Indigenous storytelling are circular or spiral (Dokis 2020). Modalities include intergenerational iterations of time and "the felt presence of ancestors;" the use of timeframes that span centuries, generations, or millennia in the understanding of significant events; the "knowledges arising from enduring occupancy of a particular 
homeland, including attunement to animal and climatic periodicities;" and the affective and material legacies of dispossession (Rifkin 2017, p. 19). Although Indigenous stories may reach far back in time, they are neither static nor ahistorical. As Rifkin writes, affective and bodily connections to ancestors, land, and nonhuman persons provide a "sense of direction," "historical density," collective belonging, and intergenerational inheritances as an expression of "temporal sovereignty" that influences "how a people moves toward the future" (Rifkin 2017, pp. 30-32).

With regard to audiences, Archibald explains that one cannot be just a "passive observer or armchair reader" (2008, p. 32). There is an interrelationship between storytelling, story, and the listener. To make meaning of what has been read or heard, one must be an active participant in the story and think critically about "one's own historical, cultural and current context in relation to the story being told" (ibid). This process involves heart, mind, body, and soul. As Fredda Paul told me:

I like to have people think through what I have told them. Let them decide what's going on, what really happened. It has to come from the heart, when they speak to me, and not just talking from the head.

Fredda does not want to speak to people if they are not coming from the heart. Storytelling was passed down to him from his grandmother and other Elders. For Fredda, storytelling is a spiritual practice where you learn knowledge from the ancestors. Fredda would also like future generations to know what happened in the schools and to learn about this part of his culture that is in danger of rapidly disappearing. As he stated, "People used to sit around in the winter and tell stories. Now, the TV is the center of attention or people jump in the car and go somewhere. Back in the day, there were only two cars on the reserve" (Skype call, 15 February 2018). In these comments, Fredda affirms Archibald's observation that Indigenous storytelling involves: respect for all relationships; responsibility for cultural knowledge and ethical protocols; reciprocity in remembering and if given permission, telling the stories to others; and reverence for oral tradition and the preciousness of what is being shared (Archibald 2008).

What might enacting these principles mean for settler witnesses? Or, as environmental educators Lisa Korteweg and Emily Root ask, "how can we [settlers] open our minds to listen and [our hearts] to learn?" (2016, p. 180). Here, the pedagogical literature helps inform that third level of witnessing that Laub identifies, witnessing the process of witnessing itself. Métis scholar Judy Iseke (2011, p. 323) explains:

The listener will also experience struggles of his or her own in the process of acting as witness to the trauma witness (storyteller). The listener is, therefore, both a witness to the trauma of the one sharing the story and a witness to his or her own experiences of the trauma of the story and reactions to it.

This is a process, Regan advises, where we must be willing to risk vulnerability, humility, and discomfort and to "embrace IRS stories as powerful teachings - disquieting moments in which we can change our beliefs, attitudes, and action" (Regan 2010, p. 13).

For settler witnesses, hearing stories of residential schools and ongoing colonialism involves a complex and difficult set of emotions: anger, shame, guilt, fear, denial, anxiety, hope, admiration, curiosity, and so forth. Korteweg and Root argue that settlers 
"need to acknowledge and discuss their affective processing as they contend with their settler positionality in the Indigenous-non-Indigenous relationship that constitutes Canada" (2016, p. 182). They call this processing of emotions "affective learning" or "affective reckoning," and it is "a critical step forward towards a decolonizing process" (ibid., p. 180). We must engage with our full array of emotions and not rest on a too easily assumed empathy that, as noted earlier, may in fact suppress difference, reinforce oppressive relationships, or treat victims as helpless and without agency.

Empathy and other emotions can do their job correctly if channeled into a selfreflexive learning process. This involves "vigilance" and wakefulness," which Oliver explains as "a movement beyond ourselves toward otherness" and "telling oneself to the other," even if I never speak the narrative of myself out loud (2001, 135, 206; emphasis added). Iseke describes pedagogical witnessing as "an event in which I allow the understanding of someone else's life to interrupt my own life" (2011, p. 312). In reworking our own narratives, witnessing particularly enacts the Indigenous principle of reciprocity. Our responsibility as witnesses is to share what we have learned, particularly with other settlers, and to "disrupt our settler-colonial complicity while we build respectful relations" (Korteweg and Root 2016, p. 190). I turn to the challenges of this process in the next section, reflecting on my own experiences at the TRC's national events.

\section{At the TRC: Aesthetics and Emotions}

The public sharing of testimony occurred in two different venues. The Commissioners' Sharing Panels typically took place in large hotel ballrooms with some or all Commissioners, survivors, and their support people seated on a stage at the front. Survivors were microphoned and videotaped, with their testimony livestreamed on the Internet and projected onto large screens throughout the ballroom (ballrooms were typically too large for anyone in the back half of the room to be able to see what was going on). Speakers were asked to limit their time to fifteen minutes. The smaller Sharing Circles, chaired by members of the TRC Survivors' Committee, were set up as a circle of speakers, with the audience sitting on the outside. These sessions were microphoned but they were not videotaped or livestreamed. No time limits were placed on the Sharing Circle speakers, and they were much more intimate, with smaller numbers in attendance. Both kinds of truth-sharing sessions typically lasted three to four hours at a time.

While bearing witness extends beyond the "facts," the foundational premise of truth commissions is that silence is broken and the truth is known and acknowledged. Settler ignorance and denial includes not even knowing about the schools, as was the case for me until about age twenty-five. For his part, Fredda wants to share his stories so that all people will know what happened at residential school. He told me:

It's up to the person whether they want to read about something from a book or get it from the actual person who has actually suffered. Why get your answers from a book? They're not true. I've been there. Lots of people have asked me questions, saying, 'I read this' or 'I read that.' But why read a book? The books are telling lies based on what the government has told them (Skype call, 15 February 2018). 
To recall, for years the government and churches have denied liability and downplayed the nature and extent of the schools. Survivor testimony thus serves to "reduce the number of lies," as Michael Ignatieff (1996) famously put it with respect to truth commissions.

But the TRC also went beyond factual truth: the inclusion of ceremony signaled to me, as an outsider, the sacred nature of what was occurring. Sharing sessions opened with a prayer, lighting a qulliq (an Inuit oil lamp), the burning of sweetgrass, and sometimes a drum song, while a sacred fire burned outside throughout the three or four days of the event. Survivors, through their stories, imparted the profound hurt, pain, and damage caused by residential schools. In some ways, it was the onslaught of testimony itself, for hours at time - hearing someone's voice, registering their emotions, feeling at times like you could not breathe yourself - that was deeply impactful. This embodied, affective dimension of storytelling "is unsettling and makes the listener aware of the painful intensity of these memories" (Kennedy 2008, p. 64).

This is evidenced in my field notes, which I wrote after my first two days in Halifax (prior to Fredda's timeslot), in response to the testimony of a Presbyterian minister who related a family history of drinking, fighting, sexual abuse, incest, stabbing, addiction, and overdose:

The pain is overwhelming. And I am seeing things differently. Not that I ever pathologized people, but I really see the strength and dignity that people have in the face of massive, massive social problems. It is overwhelming. I feel a fool for not having realized the extent. I have read a lot but I think it is only in these last few days that the extent of the day-to-day impact is really setting in. I realize I have no idea what it is like to live as a First Nations person. Not the bad stuff. What I have witnessed at the TRC is tremendous wisdom, strength, pride and courage (Field notes, October 28, 2011).

My response, this experience of really starting to understand, is due to the emotional impact of felt interactions and the aesthetics of the TRC proceedings. Robinson and Martin, 2016, p. 2) explain aesthetic action as "the range of sensory stimuli-images, sounds, movement- [that] have social and political effects throughout our affective engagements with them." For example, there are certain ingredients that seem to make for an emotionally appealing story: eloquence, coherence, visual impact, the "affective qualities of voice" (Vallee 2016, p. 3). This was certainly part of why Fredda's stories originally had such an impact on me:

There is a certain aesthetic to this testimony...the quietness of Leslie's voice, her calm, her sincerity, the beauty of the stories. In person, an intimacy pervaded the large conference room, and, later, watching and re-watching the video, it seems even more intimate. There is an artistic close-up shot of Fredda's hands, holding the eagle feather with the swirling smudge in the background. I didn't take notes during Fredda and Leslie's live testimony; I let the words wash over me, knowing I could watch the video later (my notes, May 27, 2016).

Numerous critics have argued that the TRC cultivated problematic modes of engagement through its aesthetic practices. The main claim is that the TRC enabled the consumption of 
trauma and the pathologization of Indigenous peoples by virtue of its "trend towards narrations of horror," (Niezen 2016, p. 922) and "certain expectations of performing victimry for a settler public" (Robinson 2016, p. 44). In particular, these critics flag the symbolic cleansing of grief that occurred, for example, in the placing of tissue-soaked tears in the sacred fire. This had the effect, Reynaud suggests, of channeling emotions away from anger because anger "tracks feelings of injustice that are incompatible with the idea of working toward a reconciled Canada" (Reynaud 2014, p. 372).

While certainly these aesthetic framings were present, it is important to recognize their origins and that such framings were not monolithic. First, although healing is undoubtedly a dominant narrative at the TRC, the emphasis on individual and intergenerational suffering, loss, and healing reflects, "however partially, Indigenous aspirations and needs" rather than simply being "imposed fabrications of the dominant society" (James 2012, p. 199). Discourses of trauma and healing arose in the context of survivor retraumatization over 20 years of disbelief, indifference, callousness, and nastiness in the legal/political system that was unwilling and unable to meet people's needs for truth, justice or healing. Correspondingly, however, it also means that settlers have learned to say "sorry" in particular ways, that is, for historic abuse and loss, but not for ongoing colonialism (Whitlock 2015).

Second, alongside public truth-sharing, the national events featured activities that explicitly addressed colonialism more broadly, such as panels on gender, treaty, and Indigenous knowledges, or the Walking with Our Sisters commemorative art installation. These are all issues addressed in the final report's 94 Calls to Action. Third, survivors could and did disrupt colonial narratives by speaking in their own language; naming their abusers; using their timeslot to challenge government policy and structures of colonialism; and expressing anger, resilience, strength, and vibrancy. ${ }^{11}$

For instance, I was party to a very challenging open microphone session at the Montreal event titled, "It Matters to Me," where anger, and even hate, were fully evident:

An older Kanien'kehá:ka (Mohawk) man talked about hanging all whites, and that Prime Minister Stephen Harper needed to be shot. His companion was intensely critical of the Catholic Church, asking, "is it your God that is corrupt or your institution?" He also talked about evil: the church as evil, the state as evil. I think this kind of talk scared the crap out of everyone in the room who was not Indigenous. Who is going to open their mouth in that atmosphere? Despite repeated requests from the session moderator, few settler Canadians spoke. Finally, journalist Shelagh Rogers, a TRC honorary witness, stood up and said, "I hear you. I feel extremely uncomfortable and thank you for that." David MacDonald [former federal Minister and member of the United Church of Canada's General Council Steering Group on Residential Schools], who had been asked to open the discussion, responded also, saying he agreed, surprisingly, with some of the strongest voices in the room and that the anger showed what a gap exists between Indigenous and non-Indigenous, the latter who are scared, confused and ignorant (Field notes, Montreal, April 26, 2013).

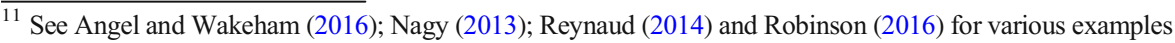
of survivors disrupting colonial narratives..
} 
For me, this session was an incredibly unsettling experience of what Coulthard (2014) identifies as righteous anger. He argues that anger should not be dismissed as unhealthy or irrational: rather, it is an Indigenous refusal to "get over" residential schools and close the "sad chapter" in Canadian history. Anger is "a sign of our critical consciousness, our sense of justice and injustice, and of our awareness of and unwillingness to reconcile ourselves with a structural and symbolic violence that is still very much present in our lives" (Coulthard 2014, pp. 126, original italics). During the session, I felt quite grateful to Rogers' and MacDonald's ability to articulate what I could not, at that time, process or express. They witnessed more than the content of the words, which were undeniably provocative, and responded in a way that did not close off the subjectivity and self-affirmation of the other. ${ }^{12}$ To be on the receiving end of such intense anger was a powerful occasioning of affective reckoning. Despite the intensity of the session, however, a very sanitized version appeared in the highlights reel at the "Call to Gather" at the end of the day. The highlights reel provided no hint of anger, fury, or discomfort. Here, the TRC missed an important teaching and learning opportunity.

The above example demonstrates that anger can be productive of the types of unsettling, affective reckoning necessary to decolonization. However, typical accounts of witnessing and testimony rely on ideas of compassion and empathy. In this, the TRC was no exception. Robinson notes that the TRC logo, "For the child taken, for the parent left behind," and its accompanying image of a mother carrying her child on her back, tapped into feelings of empathy and identification (Robinson 2016). As the mother of two boys who, in 2011, were the same age as when Indigenous children were taken away, this was for me a powerful mode of relating to survivors' stories. One of my strongest reactions to survivor testimony was the desire to go home and hug my own kids tightly. I do not think this is a wrong response, but neither is it going to contribute to decolonizing change. Powerful emotions - fear, anxiety, love - are an important starting point but are by themselves insufficient. In the next section, I turn to making meaning over time, what I learned from Fredda, and the impact of time in processes of transitional justice.

\section{Making Meaning Over Time and the Temporality of Transitional Justice}

With Indigenous storytelling, witnesses are expected to "sit with" the words and unfold the layers of what is said and not said (Qwul'sih'yah'maht, 2015, p. 192). For settlers, making meaning over time requires "working-through whatever we might find threatening in relations to otherness and difference" (Oliver 2001, p. 10). As Kortweg and Root explain, we must become "accountable for neo-colonialism by working through the affective impediments that can besiege settler decolonial learning" (2016, p.190). This will not occur overnight. For example, it took me several years, even after I had started researching residential schools, to feel comfortable and confident in calling and thinking of myself as a "settler." This is an example of the kinds of emotional blockages that Korteweg and Root talk about that allow us to avoid complicity, benefit, and responsibility. Without going through that unsettling process, without accepting the

$\overline{12}$ That said, I have no idea whether their responses satisfied the two angry men. I suspect not. 
term "settler" (i.e., on this Indigenous land that we call Canada), it is difficult to get to the issue of land dispossession and restitution.

At the start of the paper, I noted the ways in which settler temporality configures Indigeneity as ahistorical and child-like. With regard to bearing witness, Schaffer and Smith, writing in the context of Australia's inquiry into stolen Indigenous children, show how public interest in childhood narratives "had the effect of reducing informants to victims of separation, infantilized as figures of lost childhood" (Schaffer and Smith 2004 , p. 46). They were seemingly frozen in time as helpless children, and the language of "bringing them home" collapsed their life history into a singular event (ibid, p.111). Niezen further suggests that settler audiences are more receptive to narratives of stolen childhood innocence, rather than adult fury as depicted above. Audiences want "recognizable innocents...that readily lend themselves to nurturing and compassion" (Niezen 2013, p. 17) Here, the risk of empathy rears its ugly head: a sense of protective responsibility that enables further colonizing measures.

Five years after the Halifax TRC event, I contacted Fredda to seek his permission to write a paper that would explore why his stories had stayed with me for so long. I had originally wanted to profile a story Fredda shared at the TRC about rescuing his younger friend from the clutches of an abusive priest. I had been profoundly struck by this story because it showed such courage, quick thinking, and agency. It provided an important counter-narrative to public perceptions that students were passive victims who continue to lack the capacity for self-determination. Fredda's story was also quite dramatic; in my view, it made for a good story. However, I did not know, 5 years after the TRC event, that this was not a healing story for Fredda. He did not want to share it or tell it at a conference that we subsequently attended together. But that story had been available online for the last 5 years, without Fredda's knowledge.

Fredda and Leslie were both quite dismayed to discover that the testimony was online. ${ }^{13}$ For them and his counselor provided by the residential school agreement, dwelling on the "triple xxx" sad stuff, as Fredda calls it, is not helpful or healing. As we went through this paper in 2018, Fredda told me:

The TRC in Canada gave me opportunities to tell the extra sad stories. There were people to support me. There were ceremonies and prayer fires. It was hard, very hard. But it was also healing. Now it is time to let go.

However, I had never stopped to consider how storytellers might have moved onward from the time of the national event. This raises some challenging questions about the frozen-in-time nature of online testimony in the TRC archive. It also raises concerns about the ways in which audiences might abstract testimony from a real person, as I had unwittingly done, when I watched and re-watched Fredda's video and showed it to classes. The intersubjectivity of witnessing is lost, as Robinson cautions, when survivors' experiences "are engaged with as objects in an archive" (Robinson 2016, pp. 49$50)$.

Five years after the TRC, when we met in person at the conference, Fredda instead shared stories about "moving forward; pulling out of a dark place; about resiliency." He

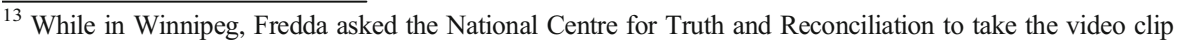
down, which it did. I suspect Fredda may not be the only survivor unaware of the online testimony.
} 
explained, "A lot of people who were in residential school don't want to look for the good things that happened to them." He shared stories about the love and laugher shared between the children during Christmas at "Shubie" and a hilarious one about the "pee game," where they would pee out the window and it would freeze before it hit the ground. He also shared moving stories about his grandmother, traditional ways, his friendship with Butch the bull, and the star chosen by the Elders that watched over him while he was in Shubenacadie. These stories keep culture, spirituality, and family and community ties alive, joining the past to the future through oral tradition and the cyclical, intergenerational temporality of Indigenous knowledges.

Fredda's stories of life in Sipayik include telling about the sacred place of whales among his people, picking the medicines with his grandmother out on the land, and respecting the power of the ocean. For me, Fredda's stories also invoke the "truth/ respect/trust relationship" which, as Archibald explains, develops between story, storytelling, and the listener (Archibald 2008, p. 20). Actively thinking about my own culture in relation to Fredda's stories, I feel their invitation to consider other ways of knowing and being. Fredda shares Indigenous understandings of what it is to be human, that is, within a larger web of nonhuman and spiritual relations. This is a relational and holistic form of knowledge, born of connections within the world that provide a tie between the past and "continuity with future generations" (Kovach 2009, p. 94). If such learning moves us to widen the concept of humanity beyond our own image, this potentially lessens one of the risks of empathy, superficial recognition of the "other." It also shifts us beyond the "epistemological privilege" of settler temporality that is "institutionalized within Indian policy" (Rifkin 2017, p. 16 and 46). This learning invites us to think about the ways in which settler society and Crown sovereignty- to reverse the problematic language of Van der Peet - needs to reconcile with Indigenous presence.

\section{Conclusion}

This paper, as an exercise in what Paulette Regan (2010, p. 17) has called "critical hope," offers an account of settler witnessing that seeks to avoid the politics of recognition and the pitfalls of colonial empathy. Witnessing is a reaching beyond ourselves through affective learning and responsiveness to the agency and selfdetermination of the other. Given the genocidal purpose of residential schools, response-ability and responsibility require an openness to and nurturing of Indigenous ways of knowing and being. Although survivor testimony is susceptible to cooptation into colonial narratives of closure and fixing the Indian problem, survivors disrupted the colonial narrative in myriad ways, including through practices of Indigenous storytelling. Reciprocating and respecting the principles of Indigenous storytelling involve heart and mind and a willingness to struggle with the stories we hear and our own reactions to them.

The TRC was a complex, polymorphous institution with its own learning curves and evolutions in the undertaking of a massive set of tasks amidst competing discursive frameworks and political agendas. It was by no means perfect. But it could and did serve as a catalyst for the ongoing unsettling of colonial beliefs and attitudes and the restorying of settler narratives in response to what was witnessed. Although the TRC is 
over, survivor testimony remains online for future research and teaching. Survivor stories of residential school will continue to play an important role in the ongoing the work of decolonization. This is because affective and embodied impact of survivor testimony has the potential to spark longer-term processes of affective learning. Furthermore, we now have the advantage of watching survivor testimony while bearing in mind the TRC's substantive Calls to Action.

However, we must be cognizant of the temporality of witnessing and transitional justice. We must be wary of how we (as teachers, researchers, settlers) handle that testimony. We must avoid freezing individuals in time or closing off the past. As Fredda's experience shows, specific residential school stories may be appropriate only at specific times within a survivor's lived experience of violence, resistance, and recovery. Thus, we may need to search out testimonials that occur outside of the TRC's temporal and other constraints in order to witness the ways that survivors and their communities live in time. As witnesses, our ongoing responsibility is to the interrelationship between past, present, and future that is embedded in the temporal sovereignty of Indigenous knowledges. Witnessing is not a one-off moment but an ethical demand to make meaning over time through response-ability to the other. In so doing, we move ourselves and settler society beyond colonial modes of recognition. This process thereby nurtures the possibility in settler witnesses of active responses that disrupt or dismantle colonial structures in order to secure Indigenous futurity.

Acknowledgments I thank Fredda Paul for his time, friendship, and wisdom in helping me write this paper. I also thank Fredda for the honor of helping to edit some of his stories as he prepares them for publication. I am grateful to Leslie Wood for our conversations, her assistance to Fredda, and her input into different drafts of the paper. I thank Fredda's family members, especially Corinna Cardamone and Aaron Michael Paul, for their wonderful hospitality when Fredda and I were in Winnipeg together for a conference and for helping Fredda go through the first draft. I thank Megan Bradley for her encouragement, David Tabachnick for his discussion of recognition, and two anonymous reviewers for their excellent suggestions.

Funding Information This research is supported by the Social Sciences and Humanities Research Council of Canada.

\section{References}

Ahmed S (2005) The Politics of Bad Feeling Australian Critical Race and Whiteness Studies Association Journal 1:72-85

Angel N (2012) Before Truth: The Labors of Testimony and the Canadian Truth and Reconciliation Commission Culture, Theory and Critique 53:199-214 doi:https://doi.org/10.1080 /14735784.2012.680257.

Angel N, Wakeham P (2016) Witnessing In Camera: Photographic Reflections on Truth and Reconciliation. In: Robinson D, Martin K (eds) Arts of Engagement: Taking Aesthetic Action In and Beyond the Truth and Reconciliation Commission of Canada. Wilfrid Laurier University Press, Waterloo, ON, pp 93-134

Archibald J-a (2008) Indigenous Storywork. UBC Press, Vancouver

Asch M (2014) On Being Here to Stay: Treaties and Aboriginal Rights in Canada. University of Toronto Press, Toronto

Balint J, Evans J, McMillan N (2014) Rethinking Transitional Justice, Redressing Indigenous Harm: A New Conceptual Approach International Journal of Transitional Justice 8:194-216 doi:https://doi.org/10.1093 /ijtj/iju004. 
Bartlett C, Marshall M, Marshall A (2012) Two-Eyed Seeing and other lessons learned within a co-learning journey of bringing together indigenous and mainstream knowledges and ways of knowing Journal of Environmental Studies and Sciences 2:331-340 doi:https://doi.org/10.1007/s13412-012-0086-8.

Bidwell KF (2012) What Stories Do: A Response to Episkenew. Canadian Literature,

Boler M (1997) The Risks of Empathy: Interrogating Multiculturalism's Gaze Cultural Studies 11:253-273

Borrows J (2017) Challenging Historical Frameworks: Aboriginal Rights, The Trickster, and Originalism. The Canadian Historical Review 98:14-135

Canada (2018a) Overview of a Recognition and Implementation of Indigenous Rights Framework. Government of Canada, Ottawa

Canada (2018b) Principles Respecting the Government of Canada's Relationship with Indigenous Peoples. Government of Canada, Ottawa

Castellano MB (2005) Updating Aboriginal Traditions of Knowledge. In: Dei GJS, Hall BL, Rosenburg DG (eds) Indigenous Knowledges in Global Contexts: Multiple Readings of our World. University of Toronto Press, Toronto, pp 21-36

CBC News (2020) Beyond 94: Truth and Reconciliation in Canada. CBC,

Cook A (2017) Intra-American Philosophy in Practice: Indigenous Voice, Felt Knowledge, and Settler Denial The Pluralist 12:74-84

Cook A (2018) Recognizing Settler Ignorance in the Canadian Truth and Reconciliation Commission Feminist Philosophy Quarterly 4:1-26

Coulthard GS (2014) Red Skin, White Masks: Rejecting the Colonial Politics of Recognition. University of Minnesota Press, Minneapolis

Cruikshank J (1998) The Social Life of Stories: Narrative and Knowledge in the Yukon Territory. University of Nebraska Press, Lincoln

de Leeuw S (2009) 'If anything is to be done with the Indian, we must catch him very young': colonial constructions of Aboriginal children and the geographies of Indian residential schooling in British Columbia, Canada Children's Geographies 7:123-140 doi:https://doi.org/10.1080/14733280902798837.

Dion SD (2009) Braiding Histories: Learning from Aboriginal Peoples' Experiences and Perspectives. UBC Press, Vancouver

Dokis T (2020) Cradling the Heart: An Anishinaabe Creation Story. Film screening and presentation, Nipissing University, North Bay. February 25.

Emberley JV (2014) The Testimonial Uncanny: Indigenous Storytelling, Knowledge, and Reparative Practices. SUNY Press, New York

Environics Institute for Survey Research (2016) Public Opinion About Aboriginal Issues in Canada 2016.

Episkenew J-A (2009) Taking Back Our Spirits: Indigenous literature, public policy and healing. University of Manitoba Press, Manitoba

Fanon F (1952) Black Skin, White Masks. Pluto Press, London

Felman S, Laub D (1992) Testimony: Crises of Witnessing in Literature, Psychoanalysis, and History. Routledge, New York

Fraser N (2000) Rethinking Recognition New Left Review 3:107-120

Green R (2012) Unsettling Cures: Exploring the Limits of the Indian Residential Schools Settlement Agreement Canadian Journal of Law and Society 27:129-148

Henry N (2010) The Impossibility of Bearing Witness: Wartime Rape and the Promise of Justice Violence against women 16:1098-1119

Ignatieff M (1996) Articles of Faith Index on Censorship 5:110-122

Imai S (2017) Consult, Consent and Veto: International Norms and Canadian Treaties. In: Coyle M, Borrows J (eds) The Right Relationships. University of Toronto, Toronto

Iseke JM (2011) Indigenous Digital Storytelling in Video: Witnessing with Alma Desjarlais Equity \& Excellence in Education 44:311-329 doi:https://doi.org/10.1080/10665684.2011.591685.

James M (2012) A Carnival of Truth? Knowledge, Ignorance and the Canadian Truth and Reconciliation Commission International Journal of Transitional Justice:1-23

James M (2017) Changing the Subject: The TRC, Its National Events, and the Displacement of Substantive Reconciliation in Canadian Media Representations. Journal of Canadian Studies 51:362-397

Jewell E, Mosby I (2019) Calls To Action Accountability: A Status Update On Reconciliation. Yellowhead Institute, Toronto

Jung C (2018) Reconciliation: six reasons to worry. Journal of Global Ethics 14:252-265 doi:https://doi. org/10.1080/17449626.2018.1507000.

Kennedy R (2008) Subversive Witnessing: Mediating Indigenous Testimony in Australian Cultural and Legal Institutions WSQ: Women's Studies Quarterly 36:58-75 
Kent L (2014) Narratives of Suffering and Endurance: Coercive Sexual Relationships, Truth Commissions and Possibilities for Gender Justice in Timor-Leste International Journal of Transitional Justice 8:289-313

King H, Pasternak S (2018) Canada's Emerging Indigenous Rights Framework: A Critical Analysis. Yellowhead Institute, Toronto

Kirmayer LJ, Gone JP, Moses J (2014) Rethinking Historical Trauma Transcultural Psychiatry 51:299-319 doi:https://doi.org/10.1177/1363461514536358.

Korteweg L, Root E (2016) Witnessing Kitchenuhmaykoosib Inninuwug's Strength and Struggle: The Affective Education of Reconciliation in Environmental Education Canadian Journal of Environmental Education 21:178-197

Kovach M (2009) Indigenous Methodologies: Characteristics, Conversations and Contexts. University of Toronto Press, Toronto

Kovach M (2010) Conversational Method in Indigenous Research First Peoples Child \& Family Review 5:4048

Lightfoot S (2016) Global Indigenous Politics: A subtle revolution. Routledge, New York

MacDonald DB (2019) The Sleeping Giant Awakens: Genocide, Indian Residential Schools, and the Challenge of Conciliation. University of Toronto Press, Toronto

Mamdani M (1996) Reconciliation without Justice South African Review of Books 46

McIvor B (2020) The Wet'suwet'en, Governments and Indigenous Peoples: A 5 Step Plan for Reconciliation vol 2020 .

Miller Z (forthcoming) Transitional Justice Temporalities. In: Douglas L, Hinton AL, Meierhenrich J (eds) The Oxford Handbook of Transitional Justice. Oxford University Press, Oxford,

Million D (2013) Therapeutic Nations: Healing in an Age of Indigenous Human Rights. University of Arizona Press, Tucson

Moon C (2009) Healing Past Violence: Traumatic Assumptions and Therapeutic Interventions in War and Reconciliation Journal of Human Rights 8:71-91 doi:https://doi.org/10.1080/14754830902717726.

Nagy R (2013) The Scope and Bounds of Transitional Justice and the Canadian Truth and Reconciliation Commission International Journal of Transitional Justice 7:52-73

Nagy R (2014) The Truth and Reconciliation Commission of Canada: Genesis and Design Canadian Journal of Law and Society 29:199-217

Nagy R, Gillespie E (2015) Representing Reconciliation: A news frame analysis of print media coverage of Indian residential schools Transitional Justice Review 1:2

Nichols J (2018) UNDRIP and the Move to the Nation-to-Nation Relationship. In: UNDRIP Implementation: More Reflections on the Braiding of International, Domestic and Indigenous Laws. Centre for International Governace Innovation, Waterloo,

Niezen R (2013) Truth and indignation: Canada's Truth and Reconciliation Commission on Indian residential schools. University of Toronto Press,

Niezen R (2016) Templates and exclusions: Victim centrism in Canada's Truth and Reconciliation Commission on Indian residential schools Journal of the Royal Anthropological Institute:920 doi: https://doi.org/10.1111/1467-9655.12497.

NIMMIWG (2019) Reclaiming Power and Place: The Final Report of the National Inquiry in Missing and Murdered Indigenous Women and Girls. National Inquiry on Missing and Murdered Indigenous Women and Girls, Ottawa

Oliver K (2001) Witnessing: Beyond Recognition. University of Minnesota Press, Minneapolis

Oliver K (2015) Witnessing, Recognition, and Response Ethics Philosophy \& Rhetoric 48:473-493

Patzer J (2019) Indigenous rights and the legal politics of Canadian coloniality: what is happening to free, prior and informed consent in Canada? The International Journal of Human Rights 23:214-233 doi:https://doi. org/10.1080/13642987.2018.1562915.

Porter E (2016) Gendered Narratives: Stories and Silences in Transitional Justice Human Rights Review 17: 35-50 doi:https://doi.org/10.1007/s12142-015-0389-8.

Qwul'sih'yah'maht (2015) Honouring the Oral Traditions of the T'at Mustimuxw (Ancestors) through Storytelling. In: Strega S, Brown L (eds) Research as Resistance: Revisiting Critical, Indigenous, and Anti-Oppressive Approaches. 2 edn. Canadian Scholars' Press/Women's Press, Toronto, pp 177-198

Regan P (2010) Unsettling the Settler Within: Indian Residential Schools, Truth Telling, and Reconciliation in Canada. UBC Press, Vancouver

Reynaud A-M (2014) Dealing with Difficult Emotions: Anger at the Truth and Reconciliation Commission of Canada Anthropologica 56:369-382

Rifkin M (2017) Beyond Settler Time: Temporal Sovereignty and Indigenous Self-Determination. Duke University Press, Durham and London 
Robinson D (2016) Intergenerational Sense, Intergenerational Memeory. In: Robinson D, Martin K (eds) Arts of Engagement: Taking Aesthetic Action In and Beyond the Truth and Reconciliation Commission of Canada. Wilfrid Laurier University Press, Waterloo, ON, pp 43-66

Robinson D, Martin K (2016) Introduction: 'The Body is a Resonant Chamber'. In: Robinson D, Martin K (eds) Arts of Engagement: Taking Aesthetic Action In and Beyond the Truth and Reconciliation Commission of Canada. Wilfrid Laurier University Press, Waterloo, ON, pp 1-20

Ross FC (2010) An Acknowledged Failure: Women, Voice, Violence and the South African Truth and Reconciliation Commission. In: Shaw R, Waldorf L (eds) Localizing Transitional Justice: Interventions and Priorities after Mass Violence,. Stanford University Press, Stanford, pp 69-91

Saeidi S, Turcotte HM (2011) Politicizing Emotions: Historicizing Affective Exchange and Feminist Gatherings International Studies Review 13:693-696

Scarry E (1985) The Body in Pain: The Making and Unmaking of the World. Oxford University Press, New York

Schaffer K, Smith S (2004) Human Rights and Narrated Lives: The Ethics of Recognition. Palgrave MacMillan, New York

Simon RI (2013) Towards a Hopeful Practice of Worrying: The Problematics of Listening and the Educative Responsibilities of Canada's Truth and Reconciliation Commission. In: Henderson J, Wakeham P (eds) Reconciling Canada: Critical Perspectives on the Culture of Redress. University of Toronto Press, Toronto, pp 129-142

Statistics Canada (2017) Ethnic and cultural origins of Canadians: Portrait of a rich heritage. Statistics Canada, Ottawa

Taylor C (1994) The Politics of Recognition. In: Gutmann A (ed) Multiculturalism: Examining the Politics of Recognition. Princeton University Press, Princeton, pp 25-73

Thielen-Wilson L (2014) Troubling the Path to Decolonization: Indian Residential School Case Law, Genocide, and Settler Illegitimacy Canadian Journal of Law \& Society 29:181-197

TRC (2015a) The Final Report of the Truth and Reconciliation Commission of Canada. Truth and Reconciliation Commission of Canada, Ottawa

TRC (2015b) Honouring the Truth, Reconciling for the Future: Summary of the Final Report of the Truth and Reconciliation Commission of Canada. Truth and Reconciliation Commission of Canada, Ottawa

TRC (2015c) The Survivors Speak: A Report of the Truth and Reconciliation Commission of Canada. Truth and Reconciliation Commission of Canada, Ottawa

Vallee M (2016) Hearing Voice: A Theoretical Framework for Truth Commission Testimony Law and Critique 27:45-61 doi:https://doi.org/10.1007/s10978-015-9168-6.

Van der Peet Rv [1996] 2 S.C.R. 507

Vizenor GR (2009) Native Liberty: Natural Reason and Cultural Survivance. University of Nebraska Press, Lincoln

Whitlock G (2015) Postcolonial Life Narratives: Testimonial Transactions. Oxford University Press, Oxford Wolfe P (2006) Settler colonialism and the elimination of the native Journal of Genocide Research 8:387-409

Woolford A (2009) Ontological Destruction: Genocide and Canadian Aboriginal Peoples Genocide Studies and Prevention 4:81-97

Publisher's Note Springer Nature remains neutral with regard to jurisdictional claims in published maps and institutional affiliations. 